\title{
Comentário sobre: $O$ FED no palco central: Navegando por águas proibidas
}

Commentary on: The FED on Main Stage: navigating by forbidden waters

Alessandro Donadio Miebach ${ }^{\text {a }}$

Gérard Duménil e Domenique Lévy exploram no texto "O FED no palco central: Navegando por águas proibidas" as respostas imediatas da autoridade monetária estadunidense a crise da Covid 19. O texto fundamentou um seminário proferido por Gérard Duménil em julho de 2020 na Universidade Federal do Estado do Rio Grande do Sul, e constitui-se em uma análise efetuada no calor dos eventos. Como de praxe na produção destes autores é apresentado um conjunto relevante de dados, que busca fornecer evidências que sustentem a análise.

Se o texto foi escrito no contexto da emergência da pandemia, suas bases analíticas se situam na prolífica produção científica dos autores dos livros A Crise do Neoliberalismo (publicado pela Boitempo, em 2013) e Managerial Capitalism (2018, sem tradução para o português). O leitor mais familiarizado com essas obras e com a produção dos autores encontrará na discussão do texto os elementos que sustentam algumas das teses associadas ao surgimento e a trajetória do neoliberalismo. Implícita nas discussões do texto encontram-se as tensões presentes no conceito do Capitalismo Gerencial e em sua articulação com as ordens sociais posteriores ao segundo Pós-Guerra, conceito este desenvolvido pelos autores em seus livros e artigos. Nas linhas que seguem irá se ressaltar dois pontos relevantes para a compreensão tanto do momento histórico do capitalismo, bem como dos desafios que irão se apresentar no futuro imediato e que estão contidos no texto de Duménil e Lévy.

Para além do pano de fundo teórico, a discussão proposta por Duménil e Lévy apresenta de maneira consistente a magnitude da resposta do Federal Reserve (FED, o banco central dos EUA) à crise da pandemia e a enorme expansão de seu balanço. Mas mais do que propriamente a expansão do balanço do FED, a contribuição do artigo reside em identificar que a autoridade monetária dos EUA passou a executar um financiamento direto dos agentes econômicos, contornando os canais convencionais de crédito. Essa ação segue a tendência anteriormente identificada pelos autores à instabilidade do capitalismo e

\footnotetext{
a Professor da Faculdade de Ciências Econômicas e do Programa de Pós-Graduação em Economia da Universidade Federal do Rio Grande do Sul (FCE e PPGE/UFRGS). Email: aledonadio@ gmail.com.
} 
a necessidade de permanentes de intervenções por parte das autoridades centrais para controlar tais tendências. As ações do FED na crise da pandemia, na visão dos autores, implicam em uma continuidade em relação às respostas à crise de 2008 , e se constituem um anátema em relação às práticas prescritas pela visão convencional da macroeconomia.

Este é o primeiro ponto que se constitui em um relevante chamado à reflexão. A ordem neoliberal estabelecida entre o final da década de 1970 e o início da década de 1980 libertou as tendências entrópicas do capitalismo, mantidas sob controle ao longo daquilo que Duménil e Lévy designam como "Compromisso do Pós-Guerra” e que se constituíram nas chamadas "décadas gloriosas" do capitalismo, a partir de 1945. Ao longo do Neoliberalismo as tendências à financeirização, à queda das taxas de acumulação de capital e à instabilidade nos mercados financeiros se acentuaram. Este processo conduziu no início do século XXI à crise de 2008, que os autores designam, com precisão, como "A crise do Neoliberalismo". A partir da crise do Neoliberalismo, Duménil e Lévy mostram que práticas consideradas nefastas para o bom funcionamento dos mercados tornaram-se necessidades recorrentes na busca da contenção das agudas instabilidades do capitalismo neoliberal. Como o texto discute, o financiamento direto via emissões do FED, um anátema, que deveria ser transitório, se converteu em prática rotineira dadas as instabilidades econômicas da última década.

Duménil e Lévy concluem sua discussão sinalizando o potencial surgimento de tensões entre o setor bancário e a autoridade monetária norte-americana, dado que a tendência de juros baixos e financiamento direto por parte do FED é de continuidade. As recentes tensões observadas nos mercados financeiros dos EUA parecem ser favoráveis às hipóteses dos autores. Ainda assim, os autores sinalizam que a trajetória atual da economia dos EUA é insustentável e exige o afastamento da dinâmica neoliberal. As duas últimas administrações dos EUA, Trump e Biden, parecem concordar com isso.

Este é o segundo ponto que suscita a atenção do leitor. O acumulo de instabilidades do capitalismo neoliberal é enfrentando exclusivamente com estratégias de mitigação. Tais estratégias não eliminam as instabilidades, apenas as mantém a níveis manejáveis, com vistas a sustentar o preço dos ativos, os fluxos de recursos e a mínima estabilidade dos estoques de riqueza financeira. Entretanto a mitigação de curto prazo implica em que não se vislumbra uma solução de continuidade para as instabilidades, em um contexto de baixo crescimento e o aumento das iniquidades sociais. Assim, o efeito do choque protagonizado pela pandemia de Covid 19 pôs a nu as extremas desigualdades sociais e a condição de pobreza de largos contingentes humanos, tanto nos países da periferia e semiperiferia do capitalismo, como até mesmo nos países do centro do sistema, cujas classes populares tiveram suas condições de vida profundamente precarizadas ao longo das décadas neoliberais. Mesmo dado esse conjunto de questões, as classes superiores não estão prontas a abdicar do conjunto de privilégios e ganhos obtidos com o neoliberalismo, o que resulta em impasses como o atual.

Ainda assim, como fica implícito na discussão proposta dor Duménil e Lévy, não há que se ter como dada a sentença de morte do neoliberalismo. Entretanto, cabe ponderar que os dois últimos governos dos EUA indicam um severo descompasso entre a estrutura 
econômica neoliberal e as expectativas e anseios da população do país. Apesar das grandes diferenças entre Biden e Trump, ambas as administrações buscaram rever, seletivamente, alguns princípios norteadores do neoliberalismo. No caso da administração Biden, a revisão tentada parece ser maior, o que tem ensejado uma maior oposição, a qual é uma amálgama de conservadores, plutocratas e beneficiários da financeirização.

Ao mesmo tempo, o governo do país se defronta com o pesado legado da pandemia sobre a economia e a sociedade norte-americana. A dúvida que se coloca reside na efetiva capacidade da sociedade norte-americana em mudar o curso traçado até o momento. $\mathrm{O}$ sucesso ou o fracasso na busca pela superação do neoliberalismo permanece uma incógnita nos EUA. 